ROCZNIKI NAUK SPOŁECZNYCH

Tom 13(49), numer $2-2021$

DOI: https://doi.org/10.18290/rns21492-11

\title{
OKSANA MITROFANOVA
}

\author{
POLITYKA FRANCJI I NIEMIEC \\ WOBEC NIEPODLEGŁEJ UKRAINY. \\ WOKÓŁ STABILIZACJI I BEZPIECZEŃSTWA
}

\section{WPROWADZENIE}

W 2021 roku Ukraina obchodzi 30-lecie odzyskania niepodległości. Jej suwerenność została przyjęta dość chłodnie przez zdecydowaną większość państw, chociaż Polska uznała niepodległość państwa sąsiedniego już 2 grudnia 1991 roku.

Analiza ewolucji podejścia wiodących państw UE do Ukrainy jest aktualnym i pilnym problemem badawczym. Ukraina dąży do przystąpienia do Unii Europejskiej i obecnie ma status partnera stowarzyszonego. Sytuacja w Donbasie jest rozstrzygana w formacie normandzkim z udziałem Francji i Niemiec. Dlatego rola tych wpływowych państw ma dla Ukrainy szczególne znaczenie.

Celem niniejszego artykułu jest analiza procesu rozwoju polityki Francji i Niemiec wobec niepodległej Ukrainy po 1991 roku. Jednym z pytań badawczych jest wpływ stereotypów historycznych na kształtowanie się polityki Francji i Niemiec wobec Ukrainy. Przyjęto, że historia białej emigracji rosyjskiej do Francji w pewien sposób wyjaśnia jej wpływ na tworzenie pozycji Francji wobec Ukrainy w latach 90. Następnym pytaniem jest badanie roli we Francji i Niemczech diaspory ukraińskiej. Warta analizy jest kwestia nuklearna w podejściu Francji i Niemiec do Ukrainy. Jako hipotezę przyjmujemy, że na początku lat 90 . Ukraina była postrzegana przez pryzmat obecności broni jądrowej i katastrofy elektrowni atomowej w Czarnobylu. Dlatego na Ukrainie wywarto presję, żeby pozbawić ją statusu nuklearnego. Jednocześnie uwaga była skupiona na pomocy w budowaniu łuku ochronnego nad sarkofagiem czarnobylskim. Przedstawiono stanowisko przywódców Francji i Niemiec

Dr Oksana Mitrofanova - Narodowa Akademia Nauk Ukrainy, Instytut Historii Powszechniej; adres do korespondencji: вул. Леонтовича 5-408, Київ 01054, Україна; е-mail: kyivparis@ukr.net; ORCID: https://orcid.org/0000-0002-2703-4919. 
wobec niepodległej Ukrainy, także w perspektywie aneksji Krymu i rosyjsko-ukraińskiego konfliktu w Donbasie. Wydzielono kilka etapów relacji francusko-ukraińskich i niemiecko-ukraińskich. Metoda historyczna została zastosowana dla zbadania wpływu historycznych stereotypów na podejście Francji i Niemców do ukraińskiej niepodległości. Jednocześnie należytą uwagę przywiązuje się do analizy tematów na poziomie lokalnym - z uwzględnieniem specyfiki państwowej, która w istotny sposób wpływa na zachowanie polityki zagranicznej. Pewne miejsce w polu badawczym zajęły tzw. momenty sytuacyjne, które często mogą mieć istotny wpływ nie tylko na stopień celowości podejmowania decyzji w wymiarze międzynarodowym, lecz także bezpośrednio na praktyczne konsekwencje rozwiązania kwestii bezpieczeństwa.

Materiałami źródłowymi badania są publikowane oficjalne stanowiska Ministerstwa Spraw Zagranicznych Francji w sprawie konfliktu rosyjsko-ukraińskiego w latach 2014-2021, wystąpienia przywódców Francji i Niemiec - François Hollande'a, Emmanuela Macrona, Angeli Merkel, wywiad z Philippe'em de Suremainem, ambasadorem Francji na Ukrainie w latach 2002-2005, przeprowadzony w Paryżu 28 września 2020, wywiad z Erikiem Fournierem, dyrektorem Departamentu Europy Kontynentalnej Ministerstwa Spraw Zagranicznych Francji w latach 2011-2014, przeprowadzony w Paryżu 8 października 2020 roku. Polityka Francji wobec niepodległej Ukrainy pojawia się w pracach naukowców: A. de Tinguy, B. Tetrais, V. Soulé. Stanowisko Niemiec wobec niepodległej Ukrainy jest analizowane w badaniach A. Drzewickiego, R. Kryvonosa. Podejście francuskie i niemieckie odnośnie do konfliktu rosyjsko-ukraińskiego zostało zaprezentowane w pracach G. Erlera, A. Gasztold, A. Lazarevoj, N. Sokolovskiej i M. Zholkvera.

\section{UWARUNKOWANIA POLITYKI FRANCJI I NIEMIEC WOBEC NIEPODLEGEEJ UKRAINY}

Na kształtowanie się polityki wiodących państw UE wobec niepodległej Ukrainy wpłynęło kilka czynników. Są to zwłaszcza historia wzajemnych stosunków, brak doświadczenia we współpracy z Ukrainą jako niezależnym państwem, interesy geopolityczne (Tertrais, 2014). Francja i Niemcy miały doświadczenie w stosunkach z Imperium Rosyjskim i ZSRR. Tym samym Rosja stała się prawowitym następcą ZSRR, a Ukraina niespodziewanie pojawiła się jako państwo o dużym terytorium i ludności, o niejasnej przyszłości i polityce zagranicznej. 
Według byłego ambasadora Francji na Ukrainie Philippe’a de Suremaina tradycyjnym problemem w stosunkach między Kijowem a Paryżem jest to, że dla niektórych francuskich polityków niepodległość Ukrainy była tylko „zbiegiem okoliczności” (wypadkiem historii - accident d'histoire) ${ }^{1}$. Jako przykład takich stereotypów przytoczmy stwierdzenie byłego prezydenta Francji, Valéry'ego Giscarda d'Estainga, że Ukraina jest dla Rosji tym samym, co dla Francji region Rhône-Alpes (Soulè, 2001).

Dziennikarka A. Lazareva uważa, że Ukraina od dawna jest dla Francuzów terra incognita. Długotrwała bezpaństwowość doprowadziła do braku jasnych symboli, które umożliwiałyby natychmiastowe odróżnienie Ukraińców od innych. Ta niepewność identyfikacji była od wieków wykorzystywana przez rosyjski ekspansjonizm, uzasadniając podbój ukraińskich terytoriów (Lazareva, 2018, s. 31).

Ukraina miała szansę na wykreowanie własnego pozytywnego wizerunku na arenie międzynarodowej. Wydaje się jednak, że została ona utracona, ponieważ na obecnym etapie Ukraina postrzegana jest przede wszystkim jako skorumpowany, biedny kraj, przez niektórych Francuzów pogardliwie nazywany białą Afryką. Masowe zubożenie ludności, poziom zarobków i życia przeciętnego Ukraińca dają podstawy do takich porównań, choć istnieją znaczne różnice między Ukrainą a Afryką. Ukraina przeżywa znaczący kryzys demograficzny, jednocześnie jej obywatele są dobrze wykształceni, podczas gdy w Afryce populacja rośnie, a wykształcenie jest na niskim poziomie.

Nie powinno się zapominać o pewnym wpływie diaspory na kształtowanie pozycji Francji wobec Ukrainy. Po rewolucji 1917 roku Francja stała się miejscem schronienia dla białych Rosjan. Rosyjscy emigranci ukształtowali imperialny pogląd na wydarzenia. W 1991 roku Związek Radziecki zakończył swoje istnienie. Jednak we Francji niepodległość Ukrainy zyskała mniejsze znaczenie niż niepodległość krajów bałtyckich. W latach 90. XX wieku rozumienie ukraińskiej polityki było znikome. We Francji potomkowie białej emigracji rosyjkiej pracowali nad stworzeniem pozytywnego wizerunku Rosji. U początków ukraińskiej niepodległości diaspora ukraińska była niewielka i nie tak aktywna jak na obecnym etapie.

W rzeczywistości Ukraina była bardziej znana i lepiej zrozumiała dla Niemiec niż dla Francji. Spowodowały to kontakty z Niemiecką Republiką Demokratyczną oraz historyczna obecność Niemiec w regionie. Niemcy zaczęły

\footnotetext{
${ }^{1}$ Wywiad z Philippe'em de Suremainem, ambasadorem Francji na Ukrainie w latach 2002-2005, przeprowadzony w Paryżu 28 września 2020 roku. W dalszej cześci artykułu wywiad również będzie przedmiotem analizy.
} 
przywiązywać dużą wagę do Ukrainy wcześniej niż inne kraje zachodnie, nawet gdy jeszcze oficjalnie nie dyskutowano o niepodległości. W 1989 roku Republika Federalna Niemiec była pierwszym państwem zachodnim, które otworzyło własny konsulat generalny w Kijowie.

W Niemczech mieszka ponad 100000 Ukraińców. Jednak ta diaspora nie jest aktywna, nie ma tu dużych organizacji ukraińskich. W Niemczech jest bardzo niewielu prawdziwych ukraińskich intelektualistów. Nic dziwnego, gdyż nie mają wsparcia ze strony Ukrainy. Ukraińcy z diaspory również nie wyróżniają się szczególnym wzajemnym wsparciem. Każdy żyje dla siebie. Jest pewna grupa „adapterów”: organizują małe imprezy, koncerty, ale nikt się tym nie interesuje (Czytaylo, 2013).

Profesor Karl Schlegel, znany niemiecki historyk i publicysta, wyjaśnia specyfikę czynnika historycznego w podejściu Niemiec do Ukrainy. Według niego Niemcy powinni wreszcie przestać utożsamiać Rosję ze Związkiem Radzieckim, przeciwko któremu nazistowskie Niemcy rozpoczęły wojnę. Należałoby wskazać, że obok Rosjan są inne narody, które doświadczyły strasznych cierpień, których winni są także Niemcy. Z drugiej strony Niemcy przejawiają pewien sentymentalizm w odniesieniu do historii stosunków między nimi a Rosjanami. Profesor zwraca uwagę, że jego rodacy powinni być realistami i uznać, że nadeszła nowa era i znowu toczy się wojna w bliskim sąsiedztwie (Zholkver, Sokolovska 2014).

Kształtowanie się polityki Francji i Niemec wobec Ukrainy odróżnia się od stanowienia polityki Polski w stosunku do Ukrainy. Czynnik historyczny odegrał i nadal odgrywa znaczącą rolę w stosunkach polsko-ukraińskich. Położenie geograficzne przyczyniło się do dobrej świadomości obu narodów. Długoletnie istnienie w I Rzeczypospolitej to wspólna historia obu państw. Fakty dotyczące istnienia języka ukraińskiego, fundamentów religijnych i kulturowych Ukrainy są znane Polakom. Zaś dla wielu ludzi w Europie Zachodniej, po 30 latach niepodległości Ukrainy, jest niejasne, że język ukraiński różni się od rosyjskiego. Jednak ważnym problemem w stosunkach dwustronnych jest rozpatrywanie kwestii historycznych na poziomie politycznym, co powoduje ochłodzenie relacji między oboma państwami. 


\section{SYNDROM „ZAGROŻENIA NUKLEARNEGO” W PODEJŚCIU DO UKRAINY}

Warto zauważyć, że zachodnioeuropejski establishment polityczny nie przewidywał nagłego zniknięcia z międzynarodowej areny potężnego przeciwnika zachodniego obozu, Związku Radzieckiego. Koniec systemu dwubiegunowego wymusił transformację istniejącego europejskiego systemu bezpieczeństwa. Do aktorów europejskiej przestrzeni strategicznej dołączył nowy, nieoczekiwany i nieprzewidywalny podmiot (a więc hipotetycznie niebezpieczny) - niepodległa Ukraina.

Jak podkreślił francuski dyplomata i polityk, Hubert Vedrine, koniec ZSRR rozpoczął swego rodzaju upadek - jakby stopił się duży lód i rozpoczął się jego dryf (Entretien du ministre des Affaires étrangères, M. Hubert Védrine, avec „France-Inter”, s. 4). Początkowo nawet założenie o możliwości zniknięcia ZSRR z mapy politycznej budziło we francuskim społeczeństwie obawy i politykę chaosu w stosunkach międzynarodowych, w szczególności w systemie bezpieczeństwa. Wskazywane było, że „brama otworzy się na nieznane, co przeraża, przynajmniej fakt, że broń jądrowa może pozostać bez opieki" (Yakushkin, 1991).

Jednym z kluczowych aspektów kształtowania strategii wiodących państw UE wobec Rosji i Ukrainy było bezpieczeństwo. W szczególności w okresie odzyskania niepodległości Ukrainy światowy klub państw nuklearnych był dość ograniczony. Dziedziczenie radzieckiego potencjału nuklearnego przez Rosję, zgodnie ze stanowiskami potężnych państw europejskich, było uprawnione. Jednak położenie niezależnego arsenału nuklearnego na terytorium niepodległej Ukrainy, trzeciego co do wielkości na świecie pod względem jego hipotetycznej pojemności, wzbudziło duże zaniepokojenie społeczności światowej. Jednocześnie Francja, trzecia potęga jądrowa na świecie, zareagowała negatywnie na obecność broni jądrowej na Ukrainie. Niewątpliwie zrodziło to logiczną kwestię kontroli broni jądrowej na terytorium Ukrainy, jej użytkowania i konserwacji. Pojawienie się suwerennej Ukrainy było tak nieoczekiwane, że francuski minister obrony, François Leotard, wskazywał: „Pożary, o których sądzono, że zostały ugaszone, płoną na mapie Europy. Ukraina i Rosja są dziś niezależne. Ryzykiem przez kilka kolejnych lat jest obecność armii nuklearnych po obu stronach. Ale jak zarządzać «ograniczonym ryzykiem jądrowym?»" (Léotard, 1994, s. 11-12).

Nie można jednak zapominać o determinantach siłowych, które dominują w globalnej przestrzeni strategicznej. Państwa nuklearne nie chciały przyjąć 
nowego, nieoczekiwanego członka. Na początku lat 90. XX wieku świat wciąż był daleki od problemów aktywnej ekspansji klubu nuklearnego i problemów programu nuklearnego w Korei Północnej. W niemieckich kręgach politycznych i mediach, a także we Francji, było wyrażane zaniepokojenie możliwością proliferacji broni jądrowej przez Ukrainę. Doprowadziło do politycznej i ekonomicznej presji na stanowisko Ukrainy w sprawie jej statusu nuklearnego (Kryvonos, 2008, s. 266). Strategia wiodących państw UE w sprawie broni jądrowej w Rosji i na Ukrainie była więc zupełnie inna. Chodziło o uznanie Rosji za prawowitego następcę broni jądrowej Związku Radzieckiego i aktywne zachęcanie Ukrainy do uzyskania statusu niejądrowego w zamian za hipotetyczną pomoc i uznanie.

Syndrom ,zagrożenia nuklearnego" wywarł zdecydowany wpływ na stosunek społeczności zachodniej do powstawania nowych państw byłego ZSRR, a zwłaszcza do niepodległej Ukrainy. Wiadomo, że stanowisko państw zachodnich na początku lat 90 . wobec państwa ukraińskiego było ogólnie powściągliwe. Ukrainę postrzegano przez pryzmat obecności broni jądrowej, katastrofy elektrowni atomowej w Czarnobylu, kryzysu gospodarczego i wewnętrznych sprzeczności.

W konsekwencji denuklearizacji Ukrainy i jej przystąpienia do Układu o nierozprzestrzenianiu broni jądrowej (Treaty on the Non-Proliferation of Nuclear Weapons) Francja przez deklarację i list Françoisa Mitterranda przyłączyła się do Memorandum budapeszteńskiego z 5 grudnia 1994 roku. Dokument podpisany przez Stany Zjednoczone, Rosję, Wielką Brytanię i Ukrainę wskazywał na jej gwarancje integralności terytorialnej oraz suwerenności.

\section{OBAWA PRZED SKUTKAMI KATASTROFY W CZARNOBYLU I PRÓBY ROZWIĄZANIA JEJ NASTĘPSTW}

Kwestia technologii jądrowych nie ograniczała się do dyskusji o dawnym istnieniu arsenału jądrowego na Ukrainie. Katastrofa w Czarnobylu w 1986 roku jest trwale związana z Ukrainą. Zwykli obywatele państw europejskich interesują się kwestiami ochrony środowiska i bezbłędnie identyfikują państwo, w którym miała miejsce awaria. Okrywa to Ukrainę złą sławną na świecie. Wiodące państwa UE nie powstrzymywały się od próby rozwiązania problemu. Należy podkreślić, że Francja aktywnie rozwija energetykę jądrową w celu uzyskania niezależności energetycznej. Pod względem udziału energii jądrowej Francja zajmuje pierwsze miejsce w świecie, a pod względem ilości 
energii wytwarzanej przez elektrownie jądrowe - drugie. Ponad $71 \%$ energii elektrycznej we Francji jest wytwarzane w elektrowniach jądrowych. Państwo to ma 58 działających reaktorów. Jest więc całkiem zrozumiałe, że podjęło ono i bierze czynny udział w działaniach w strefie Czarnobyla. Pod koniec 2016 roku francuskie konsorcjum Novarka wykonało łuk ochronny nad sarkofagiem czarnobylskim. Budowa trwała 9 lat i kosztowała 1,5 miliarda euro.

Dzięki funduszom od rządu francuskiego firma Tractebel Engineering opracowała projekt stworzenia parku energii słonecznej w strefie zamkniętej. Energia z naziemnych paneli słonecznych powinna wystarczyć dla 200 tys. gospodarstw domowych. Francja przeznaczyła 250 tys. euro na badania nad przekształceniem strefy wykluczenia w strefę, w której będą rozwijane alternatywne źródła energii (Macegora, 2018).

Niemcy przeznaczyły około $120 \mathrm{mln}$ euro na budowę nowego sarkofagu w elektrowni atomowej w Czarnobylu. Jednak w przeciwieństwie do Francji Niemcy planowały pozbyć się energii jądrowej po katastrofach w Czarnobylu i Fukushimie. W związku z tym 6 czerwca 2011 roku na szczeblu legislacyjnym rząd RFN podjął decyzję o zakończeniu produkcji energii jądrowej do końca 2022 roku.

Niemiecka minister środowiska, budowy i bezpieczeństwa reaktorów, Barbara Hendrix, przebywała w elektrowni atomowej w Czarnobylu w marcu 2016 roku. Ogłosiła, że uważa stanowisko Ukraińców odnośnie do dalszego rozwoju energetyki jądrowej za „ślepą uliczkę z kosztownym końcem” (Berlin dast' Ukrayini shche 19 mln yevro na likvidatsiyu naslidkiv Chornobyl's'koyi katastrofy, 2016).

Ukraińsko-niemiecka firma Solar Chernobyl zbudowała elektrownię słoneczną 100 metrów od nowego sarkofagu czwartego bloku energetycznego w Czarnobylu. Szacuje się, że ilość światła słonecznego jest taka sama jak w południowych Niemczech. 3800 paneli powinno zapewnić energię dla osiedla 2 tys. domów. $W$ ten projekt zainwestowano 1 milion euro, a środki mają zwrócić się w ciągu siedmiu lat (Macegora, 2018).

\section{RÓŻNICA \\ W PODEJŚCIACH WOBEC UKRAINY I ROSJI}

Zbieżność stanowisk wiodących państw UE przejawiła się w postrzeganiu Rosji jako aktora globalnego, członka Rady Bezpieczeństwa ONZ, z którym należy szukać kompromisu w rozwiązywaniu dzisiejszych problemów globalnych. 
Na początku odzyskania przez Ukrainę niepodległości była ona postrzegana głównie jako źródło potencjalnych problemów bezpieczeństwa, podnosząc kwestię statusu Floty Czarnomorskiej, statusu Krymu, losów broni jądrowej. Jednak samo terytorium Ukrainy i licząca w 1991 roku $52 \mathrm{mln}$ populacja zmusiły społeczność światową do zainteresowania się rozwojem państwa ukraińskiego.

Czołowe państwa UE w latach 90. XX wieku wyraziły nadzieję na demokratyczne przemiany w Rosji, przejrzystość i rozwój społeczeństwa obywatelskiego. Ukraińska polityka wielowektorowa była niezrozumiała dla państw zachodnich. Podobnie jak próżnia bezpieczeństwa odczuwana przez Ukrainę, która została stopniowo uwięziona w geopolitycznym uścisku dwóch bloków obronnych: NATO na Zachodzie i Układu o Bezpieczeństwie Zbiorowym Taszkentu na Wschodzie. Tym samym ukraińskie koncepcje celowości przystąpienia do NATO spotkały się z chłodną reakcją państw NATO, które radziły Ukrainie skupić się na budowaniu neutralności lub blokowały przystąpienie Ukrainy do NATO, jak podczas szczytu NATO w Bukareszcie w 2008 roku. 14 czerwca 2021 roku na ostatnim szczycie NATO w Brukseli podtrzymano decyzje z Bukaresztu z 2008 roku i zadeklarowano, że Ukraina może kiedyś zostać członkiem Sojuszu, ale po przeprowadzeniu reform. W kręgach analitycznych państw zachodnich rozwijała się teza, że Ukraina jest miejscem przecięcia różnych cywilizacji, może więc pełnić rolę swego rodzaju mostu (de Tinguy, 2006, s. 81) między Zachodem a Wschodem. Nie zauważono jednak, że generalnie mosty są strukturą, którą chcą jak najszybciej opuścić, aby być na stabilnym gruncie.

Etapy w relacjach francusko-ukraińskich

\begin{tabular}{|l|l|}
\hline \multirow{1}{*}{$1991-1996$} & $\begin{array}{l}\text { Najpierw obserwujemy intensywność dwustronnych kontaktów francusko- } \\
\text {-ukraińskich, po których następuje utrata zainteresowania ze strony Francji. } \\
\text { Reformy struktur ukraińskich nie zakończyły się sukcesem; nie zrealizowano } \\
\text { żadnego dużego projektu francuskiego. Ukraina nie była wiarygodnym } \\
\text { partnerem, co okazało się problematyczne dla Francuzów. W ten sposób } \\
\text { francuskie nadzieje związane z Ukrainą, zrodzone w latach 1991-1992, nie } \\
\text { spełniły się. }\end{array}$ \\
\hline \multirow{1}{*}{$1997-2000$} & $\begin{array}{l}\text { Zmieniło się podejście francuskich polityków do Ukrainy. Polityka ukraińska } \\
\text { wreszcie stawała się jasna wraz z konsekwencją w podejmowaniu reform, } \\
\text { a polityka wielkiego sąsiada - Rosji za czasów drugiej kadencji Borysa } \\
\text { Jelcyna - stawała się niekonsekwentna. Francuzi intuicyjnie oparli się na } \\
\text { Ukrainie w Europie Wschodniej. }\end{array}$ \\
\hline
\end{tabular}




\begin{tabular}{|c|c|}
\hline 2001-2004 & $\begin{array}{l}\text { Wizerunek Ukrainy został nadszarpnięty przez skandale, takie jak zabójstwo } \\
\text { dziennikarza Georgija Gongadze w } 2000 \text { r. czy sprzedaż radarów wojsko- } \\
\text { wych „Kolczuga” Saddamowi Husajnowi w } 2001 \text { r. Francja przestała trakto- } \\
\text { wać Ukrainę za prezydentury Leonida Kuczmy jako niezawodnego partnera } \\
\text { i zaczęła wspierać Władimira Putina. Po wydarzeniach z } 11 \text { września } 2001 \mathrm{r} \text {. } \\
\text { Francja zdała sobie sprawę, że w jej interesie jest zbliżenie się do Rosji Putina } \\
\text { w walce z terroryzmem. Od roku } 2003 \text { obserwowaliśmy wzrost liczby wizyt } \\
\text { przywódców ukraińskich w Paryżu, ale nie mogli oni zmienić jakości relacji. } \\
\text { Ukraina przygotowywała się wówczas do wyborów prezydenckich. }\end{array}$ \\
\hline 2005-2006 & $\begin{array}{l}\text { Nowa era rozpoczyna się wraz z wyborami prezydenckimi na Ukrainie i po- } \\
\text { marańczową rewolucją, podczas których nastąpiła zmiana w postrzeganiu } \\
\text { Ukrainy przez społeczeństwo francuskie. Francuzi z zainteresowaniem od- } \\
\text { kryli Ukrainę. Francja rozważała rozwój stosunków Ukrainy z UE w ramach } \\
\text { współpracy w konkretnych dziedzinach, a nie tylko w składaniu ogólnych } \\
\text { deklaracji. Odbyło się wiele francusko-ukraińskich spotkań politycznych. }\end{array}$ \\
\hline 2006-2010 & $\begin{array}{l}\text { Początek francuskiego rozczarowania w sytuacji niestabilności rządu i kry- } \\
\text { zysów parlamentarnych na Ukrainie. Jednak pojawia się chęć współpracy, } \\
\text { pomimo trudności gospodarczych, co przejawia się wejściem Ukrainy jako } \\
\text { obserwatora do organizacji La Francophonie w } 2006 \text { r. oraz przemówieniami } \\
\text { prezydenta Nicolasa Sarkozy'ego na temat „europejskiego powołania” } \\
\text { Ukrainy w latach 2007-2008 (Mitrofanova, 2009). }\end{array}$ \\
\hline $2010-2013$ & $\begin{array}{l}\text { Na Ukrainie za prezydentury Wiktora Janukowycza ustanowiono specyficzny } \\
\text { reżim polityczny. Z retrospekcji historycznej wynika, że Francja nie była } \\
\text { entuzjastycznie nastawiona do pomysłu podpisania umowy stowarzyszenio- } \\
\text { wej między Ukrainą a UE w } 2013 \mathrm{r} \text {. Według niektórych dyplomatów nie } \\
\text { powinno dojść do podpisania umowy z krajem, w którym panował specy- } \\
\text { ficzny reżim polityczny, niezgodny z wartościami UE (wywiad z Erikiem } \\
\text { Fournierem, dyrektorem Departamentu Europy Kontynentalnej Minister- } \\
\text { stwa Spraw Zagranicznych Francji w latach 2011-2014, przeprowadzony } \\
\text { w Paryżu } 8 \text { pażdziernika } 2020 \text { r.). Korupcja na Ukrainie zachęcała do } \\
\text { wspólnych interesów i wzbudzała europejską nieufność. W każdym razie re- } \\
\text { żim prezydenta Wiktora Janukowycza uznawano za wystarczająco daleki od } \\
\text { demokracji. }\end{array}$ \\
\hline 2014-2021 & $\begin{array}{l}\text { Nowy etap transformacyjny, Euromajdan, którego skutkiem było podpisanie } \\
21 \text { marca } 2014 \text { r. części politycznej umowy stowarzyszeniowej Ukrainy } \\
\text { z Unią Europejską, a } 27 \text { czerwca } 2014 \text { r. - jej drugiej części. Gdy odbyła się } \\
\text { aneksja Krymu przez Rosję i rozpoczął się konflikt o Donbas, Francja } \\
\text { i Niemcy w ramach formatu normandzkiego zostali mediatorami w rozstrzy- } \\
\text { ganiu konfliktu rosyjsko-ukraińskiego, ale na razie nie ma postępów w ro- } \\
\text { związaniu tego konfliktu. }\end{array}$ \\
\hline
\end{tabular}


Etapy w relacjach niemiecko-ukraińskich

\begin{tabular}{|c|c|}
\hline 1991-1993 & $\begin{array}{l}\text { Stosunki niemiecko-ukraińskie budowano chaotycznie, bez wsparcia koncep- } \\
\text { cyjnego. }\end{array}$ \\
\hline $1994-1997$ & $\begin{array}{l}\text { W następstwie zrzeczenia się broni jądrowej przez Ukrainę ożywiły się kon- } \\
\text { takty dwustronne niemiecko-ukrainskie na szczeblu dyplomatycznym, rozwi- } \\
\text { jają się i są wdrażane traktatowo-prawne punkty współpracy w szerokim } \\
\text { zakresie stosunków dwustronnych. }\end{array}$ \\
\hline $1998-2001$ & $\begin{array}{l}\text { Jakościowe pogłębienie relacji i stworzenie efektywnego instytucjonalnego } \\
\text { mechanizmu współpracy w sferze środowiskowej, społecznej, kulturowej } \\
\text { i gospodarczej. Po serii wzajemnych rozczarowań i nieuzasadnionych oczeki- } \\
\text { wań współpraca stała się niezbyt intensywna, ale stabilna. }\end{array}$ \\
\hline 2001 & $\begin{array}{l}\text { W stosunkach dwustronnych koncentrowano się na kwestiach poszanowania } \\
\text { praw człowieka i rozwoju instytucji społeczeństwa demokratycznego na } \\
\text { Ukrainie, a także na praktycznej realizacji głębokich reform gospodarczych. } \\
\text { Podobnie jak w stosunkach francusko-ukraińskich, wizerunek Ukrainy został } \\
\text { nadszarpnięty przez skandale, takie jak zabójstwo dziennikarza Georgija } \\
\text { Gongadze w } 2000 \text { r. czy sprzedaż radarów wojskowych „Kolczuga” } \\
\text { Saddamowi Husajnowi w } 2001 \mathrm{r} \text {. }\end{array}$ \\
\hline $2005-2010$ & $\begin{array}{l}\text { Pomarańczowa rewolucja i polepszenie stosunków z Niemcami (Kryvonos, } \\
\text { 2008, s. 277-278). }\end{array}$ \\
\hline 2010-2013 & $\begin{array}{l}\text { Za prezydentury Wiktora Janukowycza niemiecka polityka wobec Kijowa } \\
\text { opiera się na zasadzie „maksimum reform, minimum problemów”. „Celem } \\
\text { Berlina stało się uniknięcie możliwości pojawienia się trzech negatywnych } \\
\text { sytuacji, w których: Ukraina stałaby się obszarem rywalizacji szeroko rozu- } \\
\text { mianego Zachodu z Rosją; doszłoby do istotnych kryzysów i konfliktów } \\
\text { w relacjach rosyjsko-ukraińskich; na terenie postradzieckim - mimo } \\
\text { uwzględnienia rosyjskich interesów - nastąpiłaby swoista monopolizacja } \\
\text { wpływów Moskwy” (Drzewicki, 2019, s. 66). }\end{array}$ \\
\hline $2014-2021$ & $\begin{array}{l}\text { Po Euromajdanie Niemcy wystąpiły w roli mediatora, razem z Francją, } \\
\text { w rozstrzyganiu konfliktu rosyjsko-ukraińskiego, chociaż te państwa nie pod- } \\
\text { pisały Memorandum Budapeszteńskiego z } 5 \text { grudnia } 1994 \text { r., które gwaranto- } \\
\text { wało Ukrainie integralność terytorialną oraz suwerenność. }\end{array}$ \\
\hline
\end{tabular}

\section{FRANCJA I NIEMCY \\ WOBEC KONFLIKTU ROSYJSKO-UKRAIŃSKIEGO}

Przedstawiciele państw europejskich starali się pomóc w rozwiązaniu sytuacji na Ukrainie na początku 2014 roku poprzez negocjacje, które prowadził prezydent Wiktor Janukowycz z opozycją. Dzięki temu 21 lutego 2014 roku podpisano porozumienie o uregulowaniu kryzysu na Ukrainie. Sygnatariuszami 
porozumienia byli: prezydent Ukrainy - Janukowycz, lider frakcji parlamentarnej partii UDAR - Witalij Kliczko, lider frakcji parlamentarnej „Batkiwszczyna” (Ojczyzna) - Arsenij Jaceniuk, lider frakcji parlamentarnej „Swoboda" (Wolność) - Ołeh Tiahnybok. W imieniu UE porozumienie zostało zatwierdzone przez Ministra Spraw Zagranicznych Niemiec - Franka-Waltera Steinmeiera, Ministra Spraw Zagranicznych Polski - Radosława Sikorskiego oraz dyrektora Departamentu Europy Kontynentalnej Ministerstwa Spraw Zagranicznych Francji - Erica Fourniera.

Panuje opinia, że intencje zachodnich sygnatariuszy były różne. Dla Francji priorytetem było zorganizowanie demokratycznych wyborów z udziałem Julii Tymoszenko, która miała zostać zwolniona z więzienia. Dla Niemiec ważne okazało się uniknięcie napięć z Rosją. Dla Polski kluczowe było zwiększenie wpływów na Ukrainie. Zdaniem francuskich dyplomatów błędem było odwiedzanie Majdanu z przedstawicielami państw zachodnich, którzy w 2014 roku w różnym stopniu brali udział w rozmowach politycznych. Dlatego fakt odwiedzania Majdanu przez Victorię Nuland postrzegano we Francji jako niewłaściwy krok polityczny, pretekst używany przez Rosję do ,przedstawiania wydarzeń na Majdanie jako zamachu stanu zorganizowanego przez Amerykanów i Europejczyków”2.

Aneksja Krymu i udział Rosji w konflikcie na Donbasie postawiły ,,[...] Niemcy w niezręcznej sytuacji, gdyż dotychczas opowiadały się za rozwijaniem partnerstwa z Rosją, również na płaszczyźnie bezpieczeństwa" (Gasztold, 2018, s. 159).

Francja i Niemcy zainicjowały format normandzki. 6 czerwca 2014 roku w Benouville w Normandii spotkali się przywódcy Francji, Niemiec, Rosji i Ukrainy, aby świętować 70. rocznicę operacji „Overlord” i otwarcie drugiego frontu II wojny światowej. W ten sposób powstał format normandzki, rodzaj spotkań w formacie czterostronnym - Ukraina, Niemcy, Francja, Rosja - w celu rozwiązania konfliktu zbrojnego we wschodniej Ukrainie. Niemcy nie są sygnatariuszem Memorandum Budapeszteńskiego, ale stały się aktywnym uczestnikiem formatu normandzkiego z Francją. Kanclerz Angela Merkel zaznaczyła, że sprawa ukraińska jest dla niej najtrudniejsza (Merkel' nazvala viynu $v$ Ukrayini nayskladnishym dlya neyi pytannyam, 2017).

Układ priorytetów taktyki Niemiec w rozwiązaniu sytuacji na Ukrainie świadczy o zrozumieniu, że w przypadku zaostrzenia procesu negocjacyjnego tematyką Krymu szanse na sukces stają się jeszcze mniejsze. Dlatego ważne są sekwencja działań i ustalanie priorytetów. A najwyższym priorytetem dla Niemiec jest brak ofiar cywilnych w konflikcie we wschodniej Ukrainie.

\footnotetext{
${ }^{2}$ Wywiad z Erikiem Fournierem.
} 
Tylko wtedy temat Krymu można konkretnie umieścić w porządku obrad negocjacji (Erler, 2017, s. 15).

W Niemczech wciąż są poważne wątpliwości co do tego, czego się spodziewać od W. Putina. Przede wszystkim błędne jest zrozumienie stanowiska i celów obecnego rządu rosyjskiego. Widać to w kwestiach energetycznych i projektu Nord Stream 2, a także w dyskusjach na temat sankcji wobec Rosji z powodu okupacji przez to państwo części Ukrainy. Już od początku aneksji Krymu i wojny we wschodniej Ukrainie nikt nie powinien pytać o to, dlaczego uniezależnienie energetyczne Niemiec, Ukrainy i Europy jest tak ważne. Jedność UE i przyjazne stosunki ze Stanami Zjednoczonymi są więc kluczowe. W tym celu UE i Stany Zjednoczone muszą współpracować i nie pozwalać na grę przeciwko sobie (Kosmel', 2017, s. 37).

Prezydent Francji F. Holland opowiedział się za dyplomatycznym rozwiązaniem konfliktu we wschodniej Ukrainie. Po rozmowach z A. Merkel w Kijowie z prezydentem Petrem Poroszenką 5 lutego 2015 roku oraz w Moskwie z W. Putinem 6 lutego 2015 roku, powiedział, że jest zwolennikiem przyznania znaczącej autonomii separatystom we wschodniej Ukrainie oraz utworzenia strefy zdemilitaryzowanej o szerokości od 50 do $70 \mathrm{~km}$ po obu stronach obecnej linii styku na wschodzie (Avtonomiya separatystam ta demilitaryzovana zona - tse plan Frantsiyi, 2015).

W dniach 11-12 lutego 2015 roku odbyło się w Mińsku spotkanie w formacie normandzkim. Efektem rozmów był zestaw działań służących realizacji uzgodnionego na szczycie protokołu z Mińska.

Oficjalne stanowisko Francji w sprawie konfliktu rosyjsko-ukraińskiego w latach 2014-2021 jest publikowane na stronie francuskiego Ministerstwa Spraw Zagranicznych. Konflikt między Ukrainą a Rosją powstał po kryzysie politycznym na Ukrainie pod koniec listopada 2013 roku. Przynależność tzw. zielonych ludzików do rosyjskich sił zbrojnych jest jasno określona. Wskazuje się, że „,[...] na Krymie zamaskowani rosyjscy żołnierze bez żadnych insygniów przejmują kontrolę nad wszystkimi strategicznymi obiektami w regionie. 16 marca 2014 r. zostało zorganizowane «referendum» w sprawie niepodległości i przystąpienia do Federacji Rosyjskiej. Ta aneksja nie jest uznawana przez społeczność międzynarodową" (Situation en Ukraine: la position de la France, 2020).

Francja nie uznaje i nie uzna nielegalnej aneksji Krymu. Przymusowa zmiana granic jest sprzeczna $\mathrm{z}$ prawem międzynarodowym i zobowiązaniami podjętymi przez Federację Rosyjską. Paryż wyraża ubolewanie z powodu pogarszającej się sytuacji w zakresie praw człowieka na półwyspie, która dotyczy w szczególności Tatarów krymskich, i wzywa do uwolnienia wszystkich osób przetrzymywanych 
z naruszeniem prawa międzynarodowego" (Situation en Ukraine : la position de la France, 2020).

Francja prowadzi politykę nienaruszalności i dialogu w celu politycznego rozwiązania konfliktu. Uważa, że realizacja porozumień mińskich jest jedynym sposobem rozwiązania konfliktu, dlatego współpracuje z Niemcami w ramach formatu normandzkiego.

Liderzy czołowych państw UE: Angela Merkel i Emmanuel Macron nieustannie podkreślają konieczność przestrzegania prawa międzynarodowego i rozwiązania sytuacji na Ukrainie. 27 kwietnia 2018 roku podczas wizyty w Stanach Zjednoczonych kanclerz Niemiec stwierdziła, że współpracuje ze Stanami Zjednoczonymi przeciwko nielegalnym działaniom Rosji, takim jak aneksja Krymu i sprowokowana przez Rosję sytuacja we wschodniej Ukrainie. Dodała, że popiera stosowanie surowych sankcji wobec Rosji w celu zapewnienia integralności terytorialnej Ukrainy. Była to odpowiedź na obawy, że Stany Zjednoczone nałożą zbyt surowe sankcje na Rosję, co poważnie zaszkodzi również niemieckim firmom. Jej zdaniem zasada integralności terytorialnej, podobnie jak w przypadku Ukrainy, musi być wspierana i zabezpieczana działaniem (Merkel' pidtrymala zachyst Ukrayiny za dopomohoyu żorstkykh sankciy proty Rosiyi, 2018).

Równocześnie Angela Merkel po raz kolejny przekonuje, że skutki eksploatacji gazociągu Nord Stream 2 będą pozytywne, chociaż Ukraina sprzeciwia się budowie tego rurociągu. Przeciwnikami projektu są także Stany Zjednoczone, Polska i kraje bałtyckie (Nord Stream 2: Merkel' nahadala, shczo Jevropa vse odno kupuye haz u Rosiyi, 2021).

Czynnik historyczny i doświadczenie współpracy z Imperium Rosyjskim odegrały pewną rolę w kształtowaniu polityki krajów europejskich wobec Ukrainy. W ten sposób Rosja stała się prawowitym następcą ZSRR, podczas gdy Ukraina była postrzegana jako państwo o dużym terytorium i ludności, ale o niejasnej przyszłości i polityce zagranicznej.

Na początku lat 90. XX wieku państwa europejskie były zainteresowane uzyskaniem przez Ukrainę statusu niejądrowego. Natomiast wraz z początkiem rosyjskiej agresji na Ukrainę w 2014 roku nie były przygotowane na taki scenariusz. Rozpoczęły jednak działania w formacie normandzkim w celu rozwiązania kryzysowej sytuacji. Od 2014 roku Francja i Niemcy są mediatorami 
w rozstrzyganiu konfliktu rosyjsko-ukraińskiego w Donbasie. Na razie nie ma jednak postępów w rozwiązaniu tego konfliktu o niskiej intensywności.

Przyszłość polityki Francji i Niemiec wobec Ukrainy zależy w dużej mierze od osobistych poglądów politycznych prezydenta Francji i Kanclerz Niemiec. W istotny sposób determinują one politykę zagraniczną tych państw. Ukraina jest obecnie na liście działań Europy. Likwidacja znaczącej korupcji, uregulowanie sytuacji z Rosją oraz następstwa sankcji dla gospodarek narodowych UE są priorytetami w debacie politycznej UE wobec Ukrainy. Rosja pozostaje głównym graczem w europejskiej przestrzeni strategicznej, mimo nałożonych sankcji i wezwań do przestrzegania prawa międzynarodowego. Przywódcy czołowych państw europejskich podkreślają potrzebę kontynuowania dialogu z Rosją (Mitrofanova, 2021), a niektóre kręgi polityczne i biznesowe wzywają własne rządy i przywódców do zniesienia sankcji wobec Rosji z korzyścią dla gospodarek narodowych.

Długofalowej strategii Francji wobec Ukrainy nie można przewidzieć ze względu na wiele różnorodnych czynników, przede wszystkim trudne do określenia wyniki wyborów prezydenckich we Francji.

\section{BIBLIOGRAFIA}

Автономія сепаратистам та демілітаризована зона - иее план Франції [Avtonomiya separatystamta demilitaryzovana zona - tse plan Frantsiyi] (2015), Ukrainian Voanews, 07.02, http://ukrainian.voanews.com/content/article/2633058.html [dostęp: 05.05.2021].

Берлін дасть Украӥні ще 19 млн євро на ліквідацію наслідків Чорнобильської катастрофи [Berlin dast' Ukrayini shche $19 \mathrm{mln}$ yevro na likvidatsiyu naslidkiv Chornobyl's'koyi katastrofy] (2016), 22.04.2016, https://www.5.ua/amp/suspilstvo/berlin-dast-ukraini-shche-19mln-ievro-na-likvidatsiiu-naslidkiv-chornobylskoi-katastrofy-112255.html [dostęp: 15.02.2021].

Czytaylo O. (2013), Ольга Самборська: «В Німеччині жити легше, коли відмовишся від своєї ментальності» [Ol'ha Sambors'ka: «V Nimechchynizhyty lehshe, koly vidmovyshsya vid svoyeyi men-tal'-nosti»], Високий Замок [Vysokyy Zamok] 29.01.2013, https://wz.lviv.ua/arti cle/121951-olha-samborska-v-nimechchyni-zhyty-lehshe-koly-vidmovyshsia-vid-svoiei-mental nosti [dostęp: 03.03.2020].

Drzewicki A. (2019), Problem NATO $w$ relacjach niemiecko-ukraińskich $w$ XXI wieku. Zarys zagadnienia, Roczniki Nauk Społecznych, nr 11(47), s. 53-78.

Entretien du ministre des Affaires étrangères, M. Hubert Védrine, avec “France-Inter” (1999), La politique étrangère de la France. Textes et documents, Novembre-décembre, s. 4-7.

Erler G. (2017), Для Німеччини беззаперечним є той факт, щзо без виконання всіх пунктів Мінська не може бути повного припинення санкиій [Dlya Nimechchyny bezzaperechnym ye toy fakt, shcho bez vykonannya vsikh punktiv Mins'ka ne mozhe buty povnoho prypynennya sanktsiy], Український Тиждень [Ukrayins'kyy Tyzhden'], nr 3(515), s. 14-15.

Gasztold A. (2018), Koncepcja bezpieczeństwa Niemiec, [w:] R. Zięba (red.), Bezpieczeństwo międzynarodowe w XXI wieku, Warszawa: Wydawnictwo Poltext, s. 157-171.

Kosmel' М. (2017), Кремль праџююе з усіма силами, які йдуть на контакт, для дестабілізації 
західних демократій [Kreml' pratsyuye z usima sylamy, yaki ydut' na kontakt,dlya destabilizatsiyi zakhidnykh demokratiy], Український Тиждень [Ukrayins'kyy Tyzhden'], nr 36(512), s. 37-38.

Kryvonos R. A. (2008), Украӥнсько-німецькі відносини [Ukrayins'ko-nimets'ki vidnosyny], [w:] Украӥна в постбіполярній системі міжнародних відносин, ред. Л.В. Губерський, Київ: Київський Університет [Ukrayina v postbipolyarniysystemi mizhnarodnykh vidnosyn, red. L.V. Hubers'kyy, Kyyiv: Kyyivs'kyy Universytet], s. 264-282.

Lazareva A. (2018), Навшпиньки понад прірвою [Navshpyn'ky ponad prirvoyu], Український Тиждень [Ukrayins'kyy Tyzhden'], nr 9, s. 31-32.

Léotard F. (1994), La France et le "nouveau monde”, Politique internationale (hiver), nr 62, s. 9-23.

Macegora Е. (2018), Зона отчуждения - «чернобыльская мекка» или перспективный инвестпроект для международных компаний [Zona otchuzhdeniya - «chernobyl'skaya mekka» ili perspektivnyy investproyekt dlya mezhdunarodnykh kompaniy], Realist, https://re alist.online/article/zona-otchuzhdeniya-chernobylskaya-mekka-ili-perspektivnyj-investproektdlya-mezhdunarodnyh-kompanij [dostęp: 03.05.2021].

Меркель назвала війну в Украӥні найскладнішим для неї питанням [Merkel' nazvala viynu v Ukrayini nayskladnishym dlya neyi pytannyam] (2017), 19.09.2017, LB.ua, https://lb.ua/world/2017/09/19/ 376939_merkel_nazvala_voynu_ukraine_samim.html [dostęp: 04.01.2021].

Меркель підтримала захист Украӥни за допомогою жорстких санкиій проти Росї [Merkel' pidtrymala zakhyst Ukrayiny za dopomohoyu zhorstkykhsanktsiy proty Rosiyi] (2018), 27.04.2018, Ukrainian Voanews, https://ukrainian.voanews.com/a/merkel-ukraina/ 4368021.html [dostęp: 17.04.2021].

Mitrofanova O. (2009), Les péripéties du dialogue franco-ukrainien, 15.05.2009, Centre Thucydide, https://www.afri-ct.org/2009/les-peripeties-du-dialogue-franco2089/ [dostęp: 07.05.2021].

Mitrofanova O. (2021), Складнощі розуміння: як бачать Україну франиузькі дипломати [Skladnoshchi rozuminnya: yak bachat' Ukrayinu frantsuz'ki dyplomaty] 15.02.2021, Свропейська правда [Evropeys'ka pravda], https://www.eurointegration.com.ua/articles/2021/02/ 15/7119752/ [dostęp: 12.05.2021].

Nord Stream 2: Меркель нагадала, що Європа все одно купує газ у Росії [Merkel' nahadala, shcho Yevropa vse odno kupuye haz u Rosiyi] (2021), 04.2021, Ukrinform, https://www.ukrin form.ua/rubric-world/3231301-nord-stream-2-merkel-nagadala-so-evropa-vse-odno-kupue-gazu-rosii.html [dostęp: 30.04.2021].

Situation en Ukraine : la position de la France (2020), Ministère de l'Europe et des Affaires étrangères, 06.2020, https://www.diplomatie.gouv.fr/fr/dossiers-pays/ukraine/situation-enukraine-la-position-de-la-france/ [dostęp: 04.05.2021].

Soulé V. (2001), Ukraine, l'instable équilibre entre Est et Ouest, Libération, 20.06, https://www.libera tion.fr/tribune/2001/06/20/ukraine-l-instable-equilibre-entre-est-et-ouest_368589/ [dostęp: 06.05.2021].

Tertrais B. (2014), France and the Ukraine crisis: A delicate balancing act, European Leadership Network, 10.03, https://www.europeanleadershipnetwork.org/commentary/france-and-theukraine-crisis-a-delicate-balancing-act/ [dostęp: 11.05.2021].

Tinguy De, A. (2006), Le triangle Kiev-Bruxelles-Moscou : l'impact de la "révolution orange » et de la présidence Iouchtchenko (janvier-2005-aout 2006), Revue d'études comparatives Est-Ouest, nr 37, s. 81-118.

Yakushkin D. (1991), Ельциин во Франции: просчетьл с двух сторон [El'tsyn vo Frantsyy: proschetы s dvukh storon], Московские Новости, 28.04.

Zholkver M., Sokolovska N. (2014), Украӥнська криза $і$ німечький “комплекс провини” [Ukrayins'kakryza i nimets'kyy “kompleks provyny"], DW, 12.12, https://www.dw.com/uk/українсь ка-криза-і-німецький-комплекс-провини/а-18125946 [dostęp: 1.05.2021]. 


\title{
POLITYKA FRANCJI I NIEMIEC WOBEC NIEPODLEGEEJ UKRAINY. WOKÓŁ STABILIZACJI I BEZPIECZEŃSTWA
}

\begin{abstract}
Streszczenie
Artykuł analizuje kształtowanie się polityki głównych państw UE wobec niepodległej Ukrainy. Wskazano, że na ów proces wpłynęło kilka czynników, m.in. historia stosunków między poszczególnymi państwami a Imperium Rosyjskim i ZSRR, brak doświadczenia we współpracy z Ukrainą jako niezależnym państwem, interesy geopolityczne. W niemieckich i francuskich kręgach politycznych oraz w mediach wyrażono zaniepokojenie możliwością proliferacji broni jądrowej przez Ukrainę, co z kolei doprowadziło do politycznej i ekonomicznej presji na stanowisko Ukrainy w sprawie jej statusu nuklearnego. Artykul potwierdza, że kwestia technologii jądrowych nie ograniczała się do dyskusji o dawnym istnieniu arsenału jądrowego na Ukrainie. Francja i Niemcy biorą czynny udział w działaniach w strefie Czarnobyla. Czołowe państwa UE w latach 90. XX wieku wyraziły nadzieję na demokratyczne przemiany w Rosji, przejrzystość i rozwój społeczeństwa obywatelskiego. Ukraińska polityka wielowektorowa była niezrozumiała dla państw zachodnich. Podobnie jak próżnia bezpieczeństwa odczuwana przez Ukrainę, która została stopniowo uwięziona w geopolitycznym uścisku dwóch bloków obronnych: NATO na Zachodzie i Układu o Bezpieczeństwie Zbiorowym Taszkentu na Wschodzie. Od 2014 r. Francja i Niemcy w formacie normandzkim są mediatorami w rozstrzyganiu konfliktu rosyjsko-ukraińskiego na Donbasie, ale na razie nie ma postępów w rozwiązaniu tego konfliktu o niskiej intensywności.
\end{abstract}

Słowa kluczowe: Ukraina; Francja; Niemcy; Rosja; Unia Europejska; Sojusz Północnoatlantycki.

\section{POLICY OF FRANCE AND GERMANY TOWARDS INDEPENDENT UKRAINE. AROUND STABILITY AND SECURITY}

\section{Summary}

This essay provides the shaping of the leading EU countries' policy towards independent Ukraine. It examines that it was influenced by several factors: including the history of relations between each country with the Russian Empire and the USSR, and the lack of experience in cooperation with Ukraine as an independent state, and geopolitical interests of each state. The German political circles and the media as well as the French ones have been expressed their concern over the possible proliferation of nuclear weapons by Ukraine, which in turn has led to political and economic pressure on Ukraine's stance on its nuclear status. The essay proves that the issue of nuclear technologies was not limited to the discussion of the former existence of a nuclear arsenal in Ukraine. France and Germany take an active part in the activities in the Chernobyl zone. Leading EU countries in the 1990s hoped there will be democratic changes in Russia, transparency and the development of civil society. Ukraine's multi-vector policy was incomprehensible to Western countries, as was the security vacuum felt by Ukraine, which was gradually trapped in the geopolitical grip of two defense blocs: NATO in the West and Collective Security Treaty Organisation (Tashkent Pact) in the East. Since 2014, France and Germany have been mediators in the resolution of the Russian-Ukrainian conflict in Donbas in the framework of Normandy format, but so far there is no progress in resolving this low-intensity conflict.

Keywords: Ukraine; France; Germany; Russia; the European Union; the North Atlantic Alliance. 